Critical Election or Frozen Cleavages? How Voters Chose Parties in the 2014

Ukrainian Parliamentary Election

\title{
Electoral Studies
}

Paul Chaisty and Stephen Whitefield

Accepted 14 August 2018

\begin{abstract}
Ukraine's 2014 parliamentary election, which took place in the aftermath of the Maidan revolution of February 2014 and at the height of war in the East of the country, appeared to produce significant party political realignment. In particular, support for parties that had represented the Russian element of the ethno-linguistic/geo-political cleavage that had dominated electoral competition in Ukraine since independence collapsed. The paper considers whether 2014 was a 'critical' or 'realigning' election for Ukraine. Our argument is that the 2014 election lacked the conditions that critical elections theory posits as necessary and that, on the contrary, there are strong theoretical reasons to expect cleavage stability in these volatile electoral circumstances. We offer evidence for this continuity drawn from surveys undertaken among Ukrainian voters from 1995 to 2014.
\end{abstract}




\section{Introduction}

There is broad agreement that the underlying structure to party competition in post-Soviet Ukraine was essentially frozen before 2014: ideologically it was oriented on differences in parties' stances towards the Soviet past and the country's relationship with Russia; socially, it was differentiated on regional, cultural and linguistic lines, with some important differences in views on which of these social bases were of greater importance. For a number of prominent scholars, however, the 2014 election marked a major turning point for Ukrainian party competition. The catalysts for these changes were found in the turbulent circumstances that obtained at the time of the election: the decision by President Yanukovych to flee the country following mass protests spurred in large part by demands for greater integration with the European Union (Onuch, 2015); the annexation of Crimea by Russia (Wilson, 2014); the violent conflict in Donetsk and Luhansk; the ongoing debates about the country's constitutional structure (Chaisty and Whitefield, 2017); and dramatic shifts in the nature of the parties that offered themselves for election and in the participation of voters in some parts of the country.

Undoubtedly, these developments, including those in the party system itself, had a profound impact on the politics of Ukraine in 2014 and their effects continue to this day. In this paper, however, we evaluate the 2014 Ukrainian election in light of two competing theoretical approaches. The first, 'critical elections' theory, would point to historical junctures in which elections lead to significant shifts in the ideological and social bases on which parties and voters align. While doubts certainly have been raised about the empirical basis for claims about critical elections in many contexts (Mayhew, 2002), there are nonetheless clear theoretical criteria available to evaluate whether an election is realigning (Key, 1955; Schattschneider, 1958; Burnham, 1970; Sundquist, 1973). These include the emergence of new issues and new social interests that coalesce around them, which are taken up by new parties that breakthrough to electoral success and transform the old lines of ideological and social divisions between parties. Given the great volatility and upheaval at the time of the 2014 election, there is a clear plausibility to the 'critical elections' approach. A second possibility, however, which we term 'frozen cleavages', suggests an alternative outcome. Here, we develop a perspective on party-voter alignment that highlights the likelihood that stability of the underlying attitudinal bases and social characteristics of party competition may be exactly what to expect in conditions of great political uncertainty and volatility. 
While certainly observing major changes in the supply of parties, broadly speaking, our findings speak clearly against the 'critical election' approach to the 2014 election and in favour of 'frozen cleavages'. We see therefore further continuity in the nature of party competition and party support, even despite the political exclusion of significant numbers of voters and parties that they had supported, mainly in the East of the country. These findings are not however surprising to us given our own theoretical priors about the stability of cleavages in Ukrainian politics and our interpretation of the political events that were most salient at the time of the election. In short, we did not see good reason to believe that 2014 would be a critical or realigning election at all. Moreover, we find it likely that subsequent political developments in Ukraine will sustain the underlying cleavage structures to party competition that have obtained in the post-Soviet period.

The rest of the paper proceeds as follows. First, we sketch out the circumstances in which the 2014 election was contested. With that context in mind, we then develop each of these theoretical perspectives - 'critical elections' versus 'frozen cleavages' - and how the electoral circumstances might produce both outcomes. We then draw on data from surveys undertaken by the authors since 1995, including one conducted in 2014, which allow us to analyse whether changes occurred in the underlying social characteristics and ideological bases of party competition in the country in 2014. Finally, the conclusion summarises our findings and considers the implications for party competition theory and for Ukrainian politics going forward.

\section{Parties and Elections in post-Soviet Ukraine to the Parliamentary Election of 2014}

Party competition in post-Soviet Ukrainian elections has followed a pattern seen in many Eastern Europe states since the collapse of Communism. The phenomenon of high organisational flux and party system fluidity (Gherghina, 2014), on one hand, and the relative stability of the ideological basis of party competition on the other, is a puzzle that has been the focus of much of the research on party development in post-Communist states (Evans and Whitefield, 1993; Whitefield, 2002; Tavits, 2008; Whitefield and Rohrschneider, 2009; Rovny, 2014), and this is clearly evident in the Ukrainian case.

Since 1991, Ukraine's party system has been characterised by a high degree of electoral fluidity and party fragmentation within political institutions (Birch and Wilson, 2007; Rybiy, 2013; Kuzio, 2014). New political parties have emerged on a regular basis, and 
electoral support for parties has changed significantly from one election to the next. It is revealing that of the 22 parties that served in Ukrainian cabinets between 1996 and 2012, just 7 competed in the parliamentary election of 2012, and only 3 were elected to the Verkhovna Rada. $^{1}$

The large number of parties elected in parliamentary contests has produced high levels of party fragmentation in the Rada. As can be seen in Figure 1, the level of party fragmentation between 1994 and 2006 diverged significantly from the global average. In substantive terms, Ukraine had an average effective number of parliamentary parties (ENP) of 8.6 between 1994 and 2002. ${ }^{2}$ This contrasts with the global ENP mean of 3.6 over the same period. This high number of parties puts Ukraine in a group of democratic and hybrid regimes (e.g. Benin, Brazil, Belgium and Israel) with the most fragmented party systems in the world.

\section{- Figure 1 -}

The introduction of a fully proportional party list electoral system in 2006 helped to bring levels of party fragmentation into line with the global average. In the parliamentary elections of 2006, 2007 and 2012, the mean ENP fell to 3.6. Party stabilisation was evident in other areas, too (Chaisty and Chernykh, 2014). Yet, levels of electoral volatility continued to remain comparatively high. According to Rybiy (2013, p. 410), electoral volatility stayed well above the post-Communist East European average.

Nonetheless, despite (or possibly because of) the fluidity of the Ukrainian party system, the political cleavages that structured party competition up to 2014 remained stable. The most salient ideological division centred on the so-called 'Russian Question': the geocultural divide between citizens who favoured parties that were Westward-learning in terms of cultural, geo-political and socio-economic orientation, and those citizens who supported parties that were Russian-leaning. Much of the analysis of electoral behaviour has focused on this political cleavage (Wilson 1997; Hesli et al 1998; Kubicek, 2000; O'Loughlin, 2001;

\footnotetext{
${ }^{1}$ Data calculated from the Coalitional Presidentialism Project. These data are available for download from the UK Data Service at http:// reshare.ukdataservice.ac.uk/852003/.

${ }^{2}$ The effective number of parties (ENP) weights the number of parties according to their relative size (Laakso and Taagepera 1979). These data are calculated from a dataset first assembled by Cheibub et al. (2004).
} 
Clem and Craumer, 2008; Herron, 2014). As Mykhnenko (2009, p. 283) writes in the context of the 2004 "election-cum-revolution": "There hardly exists a piece of scholarly work...that would fail to mention the impact of Ukraine's geo-cultural divide on the course and outcome of the event." In the analysis of the early post-Soviet elections, this political cleavage was understood to be shaped by party orientations towards the Communist era, and what Birch (2000a, pp. 17-18) calls the "pro-statehood anti-statehood divide"; by the time of the electoral cycles in the mid-2000s, orientations towards the past had been replaced by orientations towards the future, and in particular Ukraine's geo-political choice between closer ties with either Brussels or Moscow (Barrington and Faranda, 2009).

The orientation of political parties towards this divide broadly mirrored the left-right party political spectrum in successive parliamentary elections (Wilson and Birch, 1999; Birch, 2000a). Parties on the left, in particular the Ukrainian Communist Party, were more likely to take pro-Moscow positions than parties in the centre and on the right, with the exception of those centrist parties that sought to perpetuate elements of the "patrimonialcommunist system" (Wilson and Birch, 2007, p. 74-75), most notably the Party of Regions. Support for leftist parties was also found to correlate with regional patterns of voting. As Clem and Craumer argue, "regions within Ukraine have manifested certain (and fairly regular) preferences for political parties...” (p. 128). Put simply, parties on the left and the centrist Party of Regions were found to increase their support as the electorate moved eastwards. At the same time, while voting at the regional level followed consistent patterns, the precise socio-economic mechanisms that drove these regional effects remained unclear (Evans 2006, pp. 252-3; Harasymiw, 2005, pp. 224-5). In studying elections over the period up to 2014, researchers debated the relative importance of the divergent historical-cultural (Barrington, 2002; Kubicek, 2000; Roper and Fesnic, 2003; Darden, 2013), ethno-linguistic (Wilson, 1997; Khmelko and Wilson, 1998; Birch, 2000a), and economic (Birch 2000b; Clem and Craumer, 2008) factors that underpin Ukrainian regionalism, and no one position achieved dominance. Nor did analysts find cross-regional, socio-economic characteristics to be particularly strong predictors of voting behaviour over time. Individual-level attributes for age and economic well-being featured less prominently in this analysis. Age was found to have mixed effects on party preferences (Clem and Craumer 2008, p. 148), and the economic well-being of voters was shown to be a factor in presidential elections only (Mykhnenko, 
2009; Bloom and Shulman, 2011, Colton, 2011). ${ }^{3}$ In general, analysis of the socio-economic predictors of voting behaviour across the 1994-2012 period tended to uncover weaker effects in parliamentary contests (Harasymiw, 2005, p. 224).

However, events in 2014 threatened to transform radically this pattern of political cleavage stability. The Euromaidan protests against President Viktor Yanukovych's decision to postpone the long-awaited Association Agreement with the European Union in November 2013, led him to flee the country in February 2014 and discredited his Party of Regions; and Russia's subsequent annexation of Crimea in March 2014, and military conflict in the Eastern regions of Luhansk and Donetsk between Ukrainian government troops and Russian-backed rebels, further undermined the position of political forces sympathetic to Moscow. Large parts of the heartland of the Russian-leaning electorate were effectively disenfranchised voters in Crimea and large swathes of Donetsk and Luhansk either exited the country or did not recognise the authority of the post-Yanukovych political leadership; and elsewhere in Eastern Ukraine leading politicians like the Governor of Dnipropetrovsk, Ihor Kolomoisky, pursued a vigorous Ukrainian nationalist and pro-Western agenda.

Consequently, scholars observed that the 'Russian Question' was significantly weakened as the main dividing line in Ukrainian politics. According to Fedorenko et al. (2016, pp. 624), 2014 expedited a 'sea-change in Ukraine's electoral landscape', which was already underway. Opinion poll data, they contend, were 'more uniformly pro-Western than ever before' (p. 625), and Russian-leaning parties were forced to desist from politicising regional and linguistic differences. The presidential election in May 2014 provided further evidence of the weakening of the geo-cultural divide. The combined vote for the Party of Regions and Communist Party candidates - Mykhailo Dobkin and Petro Symonenko - was less than 5 percent; in the 2010 presidential election, the combined voted of both parties was almost 40 percent in the first round.

The results of the 26 October 2014 parliamentary elections followed this pattern. For the first time since 1991, parties representing a right-leaning, pro-Western agenda secured a large majority, and the Communist Party, which had been the largest party in the late 1990s, failed to gain one seat. Only one party associated with the Party of Regions, the Opposition

\footnotetext{
${ }^{3}$ Interestingly, research finding economic effects has tended to focus on presidential elections and has deployed aggregate-level data.
} 
Bloc, passed the 5 percent threshold, with just 9 percent of the vote; in the previous parliamentary elections of 2012, the Party of Regions was the largest party with 30 percent of the vote. The collapse in support for the pro-Russia parties was exacerbated by a large drop in turnout in Eastern and Southern regions, and by the non-participation of voters in 27 electoral districts, which automatically denied these parties access to 4.5 million voters (Shevel, 2015, p. 161). Analysts also noted that public opinion had become decidedly 'less pro-Russian' (Shevel 2015, p. 161), and that this had contributed to the success of proWestern parties. A comparison of vote totals gained by pro-Russian and pro-Western parties in 2012 and 2014, shows that in 2014 pro-Western parties fared significantly better in many Eastern and Southern regions (Shevel 2015, p. 162). This was in part the result of the new party of power, the Poroshenko Bloc, capitalising from the patronage networks that had previously belonged to the Party of Regions. Moreover, the elections produced a swing in support towards a populist party, the Radical Party, which advocated left-wing, anti-oligarch economic policies previously associated with the Communist Party.

Party system change was therefore strongly evident, especially for those voters who had a Russian/Soviet orientation. As Shevel (2015, p.15) put it, "the regional divide in Ukraine may now be more accurately described not as east versus west, but as a reduced east versus the rest”. Similarly Fedorenko et al. (2016, p. 622) described the significant weakening of "the once salient ethno-linguistic, memory-political and geopolitical division in the Ukrainian electorate." Another analysis argued the case more forcefully: "The Soviet legacy that affected and influenced earlier elections is now, like the statues of Lenin, consigned to memory" (Marples, 2015, p. 15).

Thus, the elections opened up the possibility for new cross-cutting cleavages to replace the old geo-political cleavage. But did these political circumstances, which resulted in the emergence of new parties and high levels of non-participation by voters, produce a "critical" or a "realigning" election? Or were there reasons to expect that continuity in the attitudinal bases and social characteristics of party support would be sustained even in these new conditions?

\section{Theorising Critical Elections versus Cleavage Stability}

The description just provided of the Ukrainian party landscape sets up the discussion in this section of how to evaluate whether the 2014 election was indeed critical as a number of 
scholars assert. To summarise again that claim: the 2014 election marked a pivotal and realigning moment because it (i) undermined the previous social bases to party support by substantively weakening the East within the political equation with regard to both parties and voters, (ii) weakened the ideological basis of party support in particular the cultural divide that supervened on the regional divide, and (iii) introduced a new cross-cutting division within the non-East/nationalist camp as represented by the Radical Party. These factors combined support the idea that this was a critical election.

All of these claims are of course testable, but before we go on to do so using appropriate data, it is important first to consider whether critical elections theory would provide support for such a view of 2014. Against critical elections theory, we will counterpose an alternative set of expectations grounded in theories of political cleavages that generally point towards stability in the bases of party competition, even in a context - such as applies in Ukraine - of dramatically changing party landscapes as measured by the supply of parties and the participation of voters.

\section{Critical elections theory}

Critical elections theory (Key, 1955; Schattschneider, 1958; Burnham, 1970; Sundquist, 1973: Schofield et al, 2003), developed particularly to explain historical junctures that produced rapid change in the US party system, provides a useful way to gauge the conditions under which elections may mark pivotal moments where the social, ideological and party bases of electoral competition shift radically. While much of this work is now of a certain vintage, new ways of theorising electoral competition that focus on the role of political entrepreneurs who build new parties and mobilise voters on new issues that cross-cut existing cleavages, provide a similar theoretical approach to explaining major shifts in the bases of party competition (Meguid 2005; Kriesi et al. 2006; Lynch and Whitaker 2012; Hobolt and Tilley 2016; Rohrschneider and Whitefield, 2016). We can sum up these insights as follows. Critical or realigning elections occur when:

(i) new issues arise that existing parties are unable or unwilling to incorporate in their platforms because their ownership of these issues makes a shift to take up the new issue politically problematic or because their existing base of support are strongly opposed or because they calculate that making a new issue salient will advantage a competitor party;

(ii) the new issue has its own distinctive social base of support that becomes electorally significant and/or an old base of support declines in electoral importance; 
(iii) the new issue becomes politically salient and results in the advance of the new party or parties or a significant realignment within an existing party so that it effectively takes up the new issue and social base;

(iv) the new issue/social base/party achieves electoral success and the new axis of party competition comes to shape the behaviours of other parties and public policy in subsequent elections, to form a new equilibrium until a further cycle of dealignment/realignment takes place.

Examples of such critical elections have been suggested for both the US and other countries (e.g., Hutcheson, 2011; Johnston, 2013). They include the US election of 1968, which marked the radical reshaping of the Democratic and Republican parties as a result of the civil rights movement and the loss of the Democrats' Southern base. Arguments to the same effect have been made about elections in the United Kingdom., which produced victories for New Labour elections from 1997 (Evans and Norris, 1999; Evans and Tilley, 2012). In this case, the nature of the issue divisions were altered or changed by shifts in the composition of the electorate resulting from declining turnout of particular social groups. At the same time, considerable empirical doubt (Mayhew, 2002) has been cast both on specific examples of supposed critical elections and on the rapidity of change that the term implies. These doubts do not in themselves refute the possibility that Ukraine 2014 marked a major turning point. However, judged according to the criteria just outlined, we see other reasons to question whether such a realigning moment occurred.

First, we are not convinced by evidence that a new issue had arisen in Ukrainian politics in 2014. Clearly significant change has occurred in party competition in many European countries in recent years (Dalton, 2014; Franklin, 1992), driven by new issues (social and political rights, environment etc.) and new constituencies (especially the shifting political attitudes of women, the emergence of the new middle classes (Oesch, 2008)). However, we see no such equivalent in Ukraine. Rather, the events that provoked the multiple crises, from the Maidan revolution, to the demands for greater integration with Europe, to the annexation of Crimea, to the conflict in Donetsk/Luhansk, seem to be continuous with the essentially geo-political and geo-cultural conflicts that shaped Ukrainian politics for the duration of the post-Soviet period. Indeed, the question of whether Ukraine faced East to Russia or West to Europe has already been well-documented (Whitefield, 2006). 
Second, while there is evidence that an important element of the social base of the old cleavage structure was excluded from the 2014 election because of the demise of the Party of Regions and the broader electoral boycott that resulted, this is quite different from the emergence of a new social constituency. Indeed, existing constituencies on the opposite side of the old divide may have simply been mobilised to vote in a more politically potent way on the old issues. There is one way in which the possibility of a new cleavage basis to Ukrainian party competition might have emerged in the 2014 election, namely via the rise of the Radical Party which offered a distinctly economically left-wing position within the nationalist camp and thus might satisfy the expectation from critical elections theory of a breakthrough moment for new issues, parties and constituencies. But, we note that support for the Radical Party amounted to only $7.5 \%$ of the electorate, hardly a breakthrough moment for the party system as a whole, though it may harbour change in future. Only an empirical test of the bases of support within nationalist camp parties can properly address that possibility.

\section{Frozen cleavages theory}

If the critical elections account of 2014 is not valid, what theoretical explanation would justify an expectation of continuity in the social and ideological bases in conditions of very high party level supply volatility and with evidence of compositional changes in the electorate? Such a theoretical approach is already well-established in the literature, most famously in the so-called 'freezing hypothesis' advanced by Lipset and Rokkan (1967), which predicts continuity over change because of the conditioning effects of the relationship of established parties, voter loyalties, and public policy. Moreover, these conditioning and stabilising effects may paradoxically be particularly strong rather than weak in conditions of a weakly institutionalised party system in which there is large-scale organisational turnover in party supply (Whitefield and Evans, 2006; Rovny and Polk, 2017). ${ }^{4}$

\footnotetext{
${ }^{4}$ Continuity may also be supported by the recycling of elites and party leaders into new parties in which voters have familiarity with their positions and personalities. There is some evidence of this in other Central and East European states (Gherghina, 2016), including Ukraine. Yulia Tymoshenko's and Volodymyr Lytvyn's parties have both changed their names, and Petro Poroshenko has joined different parties. However, at the same time, Viktor Yushchenko, Viktor Yanukovych, Oleksandr Moroz, Petro Symonenko have all stuck with
} 
Drawing on literature on how individuals make decisions in conditions of great uncertainty (e.g., Sniderman et al, 1991), this literature points to the importance of focal points that both voters and parties converge on precisely when organisational ties may be very weak, as was the case in Ukraine in 2014. This is because the coordination problems that parties and voters face in circumstances of limited party-voter linkages may be best addressed by the ongoing use of prior ideological focal points as a heuristic informing parties how to position themselves and voters how to interpret party stances. In the absence of new issues and constituencies, therefore, there are good reasons to think that elections will continue to be fought over the same issues even if parties themselves are unstable.

In the next sections, we will analyse opinion poll data on party voting in the 2014 parliamentary elections to ascertain whether the results of the 2014 elections did indeed mark a realignment of the cleavage structure underlying party competition in Ukraine, shifting it as critical elections theory would suggest towards new or revamped parties that compete over new issues with a new electoral base. Or whether, as we expect, despite significant changes in the supply of parties and high levels of non-voting, the election was fought over similar issues and constituencies as previous elections in the country.

\section{Method and Data}

We evaluate whether changes occurred in the attitudinal bases of party support and the demographic and socio-economic characteristics of party voters in 2014 by comparing results from a post-election survey of voter party preferences in that year with survey findings from 1995, 1998 and 2007. The earlier surveys proceeded (or preceded in the case of the 2007 survey) parliamentary elections that were held in 1994, 1998 and 2007. These survey waves cover most of the Ukrainian parliamentary elections held since the collapse of the Soviet Union. The exceptions were the election of 2002 and the election of 2006. The details of each survey are described in Appendix A, and the distribution of parties and their support for each wave is provided in Table 1.

\section{TABLE 1}

one party. Unfortunately, measurement of elite continuity however goes beyond the scope of this paper. 
To analyse the attitudinal differences between party voters, we combined responses to a number of relevant attitudinal questions. Each variable was measured using five-point agree/disagree scales ranging from strong opposition/disagreement to strong support/agreement. They covered questions that addressed attitudes related to different temporal and spatial dimensions of the geo-political cleavage:

(1) Temporal: "The dissolution of USSR was a good thing"

(2) Spatial: "Ukraine should integrate as far as possible with the European Union" OR "Ukraine should remain isolated as far as possible from the European Union" They also covered related issues associated with support for democratic values, the market and national identity:

(3) "Tell us, please, what do you think about the idea that a democracy, in which multiple parties compete for power, is the best system for governing Ukraine?"

(4) "And what do you think about the idea that a market economy, in which there is private property and economic freedom for entrepreneurs, is the best system for Ukraine?"

(5) "All minority ethnic groups in this country should have to be taught in Ukrainian"

While we observe some significant shifts in public opinion over time on many of these attitudinal questions (see the reported means of the attitudinal variables in Appendix B), it is important to our central question to distinguish between growing levels of support for various questions, such as the European Union, and the issue bases on which voters make choices about parties. As we know, support for particular parties of left and right may grow or fall depending on levels of support for left and right policies. But the same issues may be involved in how parties are selected by voters. The question we address here is whether the issue bases themselves have changed over time and in particular as a result of the upheaval of 2014.

In line with critical elections theory, we then assess whether there has been continuity in the types of voters that parties fight over. This analysis focuses on the differences between party voters in terms of their social and demographic characteristics. Here, we consider the socio-economic and demographic factors that are well-known to feature in Ukrainian elections. These are operationalised as dummy variables: region (a dummy variable for voters from the South and East of the country), language (a dummy variable for Russian 
speakers at home), age (a dummy variable for young voters aged 18-34), religion (a dummy variable for regular church attenders) and the so-called 'pocketbook' characteristics of voters (a dummy variable for voters whose standard of living had fallen over the previous 5 years). The descriptive statistics for all the attitudinal and social variables are summarised in Appendix B.

To analyse the latent attitudinal cleavages that divide or discriminate between party voters, we deploy discriminant analysis. This is an appropriate method given that our aim is to assess continuity and change of party competition as a whole at each point in time as well as where any given party stands on the given dimension of competition (Klecka, 1980; McLachlan, 2004). It is preferred over other analysis of categorical dependent variables notably multi-nominal logit regression - because it analyses dimensionality, and produces a single, aggregate statistic, which captures how each predictor estimates the clustering of all party voters into their distinct party groups. Although multi-nominal logistic regression does not capture overall dimensionality in the same way as discriminant analysis, with output being sensitive to arbitrary decisions about the party reference category, it is possible to estimate the relative significance of each variable using likelihood ratio tests. Hence, we use multi-nominal logistic regression for robustness purposes. Appendix $\mathrm{C}$ reports the results of likelihood ratio tests derived from multi-nominal logit analysis, which support the general findings of the discriminant analysis.

Also, unlike factor analysis and other data reduction techniques, discriminant analysis is a multivariate test of the variables or 'functions' that either describe or predict the differences between groups of individuals rather than single individuals. To measure the grouping variable (party voters), we asked respondents to identify the party or bloc they had voted for in the previous election (or in the case of the 2007 election, the party or bloc that they intended to vote for in a future election). ${ }^{5}$ As discriminant analysis is sensitive to the number of cases included in each group, these data only include parties that were voted for by 50 or more respondents. This meant that fewer party voters were included in the analysis of

\footnotetext{
${ }^{5}$ We recognise that the replacement of the Party of the Regions in 2014 resulted in a number and independent candidates standing. Analysis of the effects of such candidates is not possible within the confines of our data so we are unable to determine whether the attitudinal bases of support for these candidates were systematically different. However, our broad theoretical priors would incline us against the view that this was the case.
} 
the 1994 election, when plurality electoral rules returned a large number of independents and parties with thinly dispersed support. In the elections of 1998, 2007 and 2014, the introduction of mixed plurality-proportional and fully proportional rules produced more concentrated party support, and thus the number of party voters included in the analysis increased.

To analyse the differences between party voters in terms of their socio-economic and demographic characteristics, we deploy logistic regression. The assumptions that discriminant analysis makes about multivariate normal distribution are not appropriate for models that include categorical variables as predictors. ${ }^{6}$ In our analysis of demographic variables, which are all categorical in nature, we again use likelihood ratio tests derived from multi-logit analysis to estimate the relative significance of each predictor. Then we focus on the most salient discriminating variables, and calculate the probability that party voters will differ in terms of these factors. As all of our independent variables are dummies, we use binary logistic regression to calculate the marginal effects of party support on the most salient variables identified by likelihood ratio tests, while holding all the other demographic and party voter variables at their means.

The attitudinal and social variables included in our models were strongly correlated with the party preferences of voters, while at the same being in most cases sufficiently independent of each other. In the final models shown below, we include only those variables which we found to be most strongly correlated with voting preference. We also excluded any variables that were strongly inter-correlated. This meant that ethnicity, which features in much of the analysis of voting behaviour, was excluded because it is highly correlated with language and region when it comes to voting, and its statistical effects were weaker than those of language and region. ${ }^{7}$

\footnotetext{
${ }^{6}$ To our knowledge, non-parametric discriminant analysis such as ' $k$ th nearest-neighbour discriminant analysis' does not provide the post-estimation analysis that is required to estimate the effects of individual predictors on grouping variables.

${ }^{7}$ Ethnicity was only significant in the surveys for 2007 and 2014 when language and region were excluded from the discriminant analysis, and it was only significant in 2014 when language was included.
} 


\section{Results}

\section{Attitudinal analysis}

We begin our analysis of continuity and change in the attitudinal bases of party competition in Ukraine by comparing the underlying dimensionality of party competition from 1995 to 2014. Table 2 reports the results of this discriminant analysis. Column 2 shows the attitudinal issues that load most strongly on a given dimension, as well as the number of significant dimensions, and column 3 shows the strength of each dimension in terms of the percentage of variance in party support that is explained. These patterns are largely robust to likelihood ratio tests generated by multi-nominal logistical analysis (See Appendix C).

As can be seen in Table 2, in all models that include all groups of party voters containing more than 50 respondents, there is only one significant ideological dimension to party competition, which explains the overwhelming percentage of the explained variance.

\section{TABLE 2}

In each of these years, the main dimension moreover is mainly constituted by the geopolitical question of Ukraine - East to Russia or West to Europe. Where voters stood on the dissolution of the USSR was central to party competition in 1995, 1998 and 2014. This issue combines in the statistical analysis with stances on the EU in 2007 and 2014. While there are occasions in which other issues also load on to this dimension - such as the importance of language in schools in 2007 - these appear relatively congruent alongside the ongoing and powerful importance of the geo-political dimension. We see no evidence in the full models therefore of a realigning shift in the ideological bases of party support in 2014. Importantly, we also test for whether a shift in the composition of the electorate with the demise of Party of the Regions and the abstention of large numbers of voters, is associated with a shift in the nature of the ideological cleavage. The results, with or without abstainers in the South and East of the country in 2014 are remarkably similar, with the only difference being that their inclusion in the analysis as a distinctive 'party' further strengthens the explanatory power of the main function to more than $97 \%$ of the variance.

Furthermore, when we considered the possibility that generational factors were likely to have been more significant in 2014 (in particular, the attitudes younger people) we still found divisions between party voters to be solidly one-dimensional. Our analysis of a sample 
consisting of 18-45 year olds, ${ }^{8}$ showed that attitudes towards relations with the EU accounted for $92 \%$ of the variance in the clustering of party voters. Similar one-dimensional results were also observed from the analysis of the same age category in earlier survey waves. ${ }^{9}$

The expectations of critical elections theory that the transformed party and voter landscape would lead to new issues emerging to divide parties do not therefore appear to be supported. ${ }^{10}$ Moreover, it is highly probable that the return of those voters who abandoned the electoral process in 2014 will increase the salience of the geo-political dimension, as indeed appears to be the case from the very large increase in the chi-square for EU integration in the multinomial regressions reported in Appendix $\mathrm{C}$ when abstainers are treated as a distinct party. Therefore, based on our analysis, voters continue to share attitudes consistent with the historical ideological divide.

This pattern translates at the party level in the form of relatively stable attitudinal divisions between party voters. Figure 2 shows scatter plots illustrating the positioning of party voters in each legislative election: 1994, 1998, 2007 and 2014. The x-axis of each plot represents the first dimension described in Table 2; the y-axis represents the second dimension, which does not explain more than $8 \%$ of the variance in any of the models. In each diagram, a 'group centroid' indicates the mean discriminant score for each grouping of party voters.

\section{FIGURE 2}

The plots for the early elections are consistent with the extant analysis of Ukrainian parties (Wilson and Birch, 1999; Birch, 2000a). They show that the attitudinal division manifested at the party level in a left-right split. Voters for leftist parties, in particular the

\footnotetext{
${ }^{8}$ The sampling of a younger age category (e.g. 18-35 year olds) was not possible due to the small number of respondents in some of the party voter categories.

${ }^{9}$ These results are available on request.

${ }^{10}$ Only when we significantly loosened the constraints on finding new issues dividing parties by artificially excluding all voters for parties (i.e. the Opposition Bloc) that positioned themselves on the anti-dissolution/anti-EU side of the political spectrum do we find a statistically significant secondary dimension, which essentially divides centrist/nationalist parties on the economy. In line with expectations, this secondary dimension pits the economically left Radical Party against the other centrist and nationalist parties.
} 
Communist party and various socialist parties, were located on the anti-dissolution/anti-EU position, while centrist and nationalist parties like Rukh took a pro-dissolution/pro-EU stance. This left-right divide became less apparent with the demise of the Ukrainian Communist party and the rise of the Party of Regions in the 2007 elections, but its basis of support remained stable. This did not change in 2014, when party voters divided attitudinally between the Opposition Bloc (the successor to the Party of Regions) and the rest (see Figure 2d). This divide was not left-right as it had been in the 1990s. Those who voted for the most left-wing party, the populist Radical Party of Oleh Lyashko took the same position as voters of right-wing and nationalist parties on the question of EU integration, suggesting no significant realignment of Communist voters in the East.

\section{The Demographic and Socio-Economic Characteristics of Party Voters}

A similar picture of continuity emerges from our analysis of the most salient demographic and socio-economic characteristics of party voters. We first calculate the relative significance of the demographic and socio-economic predictors of party support using likelihood ratio tests derived from multi-nominal logit analysis. This test compares the goodness of fit of two multi-nominal logit models - one including the variable of interest and one excluding it. A high chi-square statistic indicates a significant reduction in the fit of the model when the variable of interest is excluded. We report the results in Table 3. We also report how the most salient demographic variables - region and language - translate at the party level. We calculate the marginal effects of the party-level predictors using binary logistic regression, holding all the other variables at their means.

Essentially, the analysis points once again to continuity in the social characteristics of party voters. Consistent with the extant research on Ukrainian voting behaviour, party voters continue to divide along regional lines. In each survey wave, the distinction between voters residing in the East/South and the rest of the country enhanced the model fit greater than any other explanatory variable. Region was also supplemented by language in all surveys. Other variables, notably age and church attendance were significant at certain times, but region and language were the only consistently salient predictors of party voting. This pattern was unchanged in 2014.

\section{- TABLE 3 -}

Again, the findings manifest at the party level in ways that are congruent with patterns observed in earlier elections by scholars of Ukrainian politics. The marginal effects reported 
in Figure 3 show that the left-right divide was strongly rooted in regional divisions in the 1990s. As Figure 3 shows, when we hold other socio-economic predictors at their means, Communist party voters were $26 \%$ more likely to reside in the East and South than Green and Rukh party voters in the 1994 and 1998 elections. Similarly, the Party of Regions relied on this electorate in 2007. According to our 2007 survey, respondents who voted for the Party of Regions were more than $70 \%$ more likely to reside in the East and the South of the country. Moving forward to 2014, our analysis also provides little evidence to suggest that centrist or nationalist parties benefited from significant realignment in the East and South of the country, despite the efforts of Eastern leaders like Ihor Kolomoisky to galvanise nationalist support in those regions. On average, only $20 \%$ of respondents who voted for pro-government and nationalist parties were likely to reside in the East or South of the country; in contrast, almost $60 \%$ of Opposition Bloc voters were likely to be from Eastern or Southern regions, holding all other predictors at their means. Not surprisingly, there was no evidence to suggest that those respondents from the East and South who abstained in 2014 were more likely to back centrist or nationalist parties.

\section{FIGURE 3}

Likewise, Ukraine's linguistic division echoes the regional division between party voters. As Figure 4 shows, leftist parties were more likely to attract the support of Russianlanguage speakers in the 1990s, with the Communist Party attracting the largest proportion of Russophones within its voting constituency. By 2007, this support had switched to the Party of Regions, with over $50 \%$ of its voters likely to be Russophones. In 2014, the picture was once again very similar. Holding all other socio-economic predictors at their means, there was a $60 \%$ probability that respondents who voted for the Opposition Bloc would be Russian language speakers. This contrasted with the $30 \%$ average probability that pro-government and nationalist voters would be Russian language speakers, which was also in line with earlier elections.

In sum, therefore, our analyses show remarkable stability over time in the nature of the ideological and social bases to party competition in Ukraine. The issue space is overwhelmingly one-dimensional and focussed on the spatial location of the country: with the Soviet past or the European Union future. The country is divided in this regard between South/East and the rest. And it remains oriented in this way even in 2014 when large swathes of voters were unrepresented and did not participate. 


\section{FIGURE 4}

\section{Conclusions}

Our analysis provides little evidence to support the notion that 2014 marked a critical election in Ukraine. The radical transformation of the party system and the significant change in the composition of the electorate, which occurred as a result of Ukraine's political upheaval in 2014 was certainly caused by the violent shock to the Ukrainian polity that followed the Maidan protests. However, the new parties and alliances that emerged did not appear to cultivate new attitudinal and socio-economic bases of support. Our findings suggest that the attitudinal and socio-economic cleavages that have defined Ukrainian politics since the early 1990s continue to dominate.

Why is this the case? We contend that the political issues that drove the crisis of 2014 were not new, and did not provide a new basis for fundamental electoral realignment. Thus, those transformational issues that are considered so central to the notion of critical elections were lacking in the Ukrainian case. The issue that divided Ukrainian citizens in 2014 - EU integration - was one variant of a bigger question that has structured the ideological orientation of Ukrainian citizens since the early 1990s: whither Ukraine? In the 1990s, this question was about time - back to the USSR or forward to Ukrainian nationhood; since the mid-2000s, the question has become one of geopolitical space: closer ties with Russia or Europe. Consequently, the crisis of 2014 reinforced well-established divisions within the Ukrainian electorate. Neither the emergence of a leftist populist party, the Radical Party, which sought to appeal to nationalist voters; nor the creation of a new centrist party of power, the Poroshenko bloc, which took over people and patronage networks from the Party of Regions in the East of the country; nor efforts at nationalist mobilisation by regional leaders in the East like Ihor Kolomoisky, were sufficient to achieve notable attitudinal or socioeconomic realignment. Instead, we find that the fundamental voter cleavages in Ukraine remain highly stable, and we suspect that they are likely to stay frozen for some time to come.

Moving forward, two factors are likely to reinforce these historical attitudinal cleavages. First, there is little evidence to suggest that the voters who abstained in large numbers in the South and East of the country in 2014 realigned attitudinally. When we included these abstainers in our analysis as a separate 'party', they took the attitudinal space 
occupied earlier by the Party of Regions: i.e. they were more likely to be pro-USSR/anti-EU integration. Therefore, the return of the abstainers at any future election is likely to augment these historical cleavages rather than transform them. Second, the patterns of voting in Ukraine repeat a pattern that we see across post-communist societies: high volatility of party systems combined with high stability of voter cleavages. This is no coincidence - the paradoxical relationship between these two phenomena may have logical foundations. In the conditions of high uncertainty caused by the fragmentation of party systems, parties and voters may be even more likely to use established heuristics (old cleavages) to ensure that they converge electorally. Ukraine certainly faced such uncertainty in 2014, which may explain why its parliamentary election in that year was more consistent than critical.

Finally, it is worth reflecting on what these findings say more generally about the possibility of critical elections versus cleavage stability in Ukraine and elsewhere. Clearly, there are occasions in which realigning elections take place, in which the social and ideological terrain shifts significantly. But, as the critical elections literature itself predicts, such changes are likely to result from the emergence of new issues founded in the interests of new sets of social actors entering the political process. It is precisely the absence of such new issues that led us to doubt the likelihood that the 2014 election would produce much change. 


\section{References}

Barrington, Lowell (2002). 'Examining rival theories of demographic influences on political support: The power of regional, ethnic, and linguistic divisions in Ukraine'. European Journal of Political Research, 41(4): 455-491.

Barrington, Lowell and Regina Faranda (2009). 'Reexamining Region, Ethnicity, and Language in Ukraine'. Post-Soviet Affairs, 25(3): 232-256.

Birch, Sarah (2000a), Elections and Democratization in Ukraine. Palgrave Macmillan: Basingstoke.

Birch, Sarah (2000b), 'Interpreting the Regional Effect in Ukrainian Politics'. Europe-Asia Studies, 52 (6):1017-1041.

Bloom, Stephen and Stephen Shulman (2011), 'Interest versus Identity: Economic Voting in Ukrainian Presidential Elections'. Post-Soviet Affairs, 27(4): 410-28.

Burnham, Walter D. (1970). Critical Elections and the Mainsprings of American Politics. University of Michigan: Ann Arbor.

Chaisty, Paul and Svitlana Chernykh (2014), 'Coalitional Presidentialism and Legislative Control in Post-Soviet Ukraine'. Post-Soviet Affairs 31(3): 177-200.

Chaisty, Paul and Stephen Whitefield (2017). 'Institutional Preferences in a Time of Crisis: Mass Attitudes towards Regional Decentralisation in War-Torn Ukraine', Political Studies, 65(4): 2017, 824-843.

Cheibub, José Antonio, Adam Przeworski, and Sebastian M. Saiegh. 2004. 'Government Coalitions and Legislative Success Under Presidentialism and Parliamentarism'. British Journal of Political Science 34(4): 565-87.

Clem, Ralph S. and Peter R. Craumer (2008). 'Orange, Blue and White, and Blonde: The Electoral Geography of Ukraine's 2006 and 2007 Rada Elections'. Eurasian Geography and Economics, 49(2): 127-151.

Colton, Timothy J. (2011) 'An Aligning Election and the Ukrainian Political Community'. East European Politics and Societies, 25(1): 4-27. 
Darden, Keith. (2013) 'Colonial Legacies, Party Machines and Enduring Regional Voting Patterns', Paper prepared for the Post-Communist Workshop, The George Washington University, Washington D.C., 7 October.

Dalton, Russell (2014). Citizen Politics: Public Opinion and Political Parties in Advanced Democracies. Sage, London.

Evans, Geoffrey (2006). 'The Social Bases of Political Divisions in Post-Communist Eastern Europe'. Annual Review of Sociology, 32: 245-270.

Evans, Geoffrey and Stephen Whitefield (1993). 'Identifying the Bases of Party Competition in Eastern Europe'. British Journal of Political Science, 23 (4), 1993, 521-548.

Evans, Geoffrey and Pippa Norris eds. (1999). Critical Elections: British Parties and Voters in Long-Term Perspective. Sage.

Evans, Geoffrey and James Tilley (2102). 'How Parties Shape Class Politics. Explaining the Decline of the Class Base of Party Support.' British Journal of Political Science, 42(1): 137161.

Fedorenko, Kostyantyn, Olena Rybiy and Andreas Umland (2016), 'The Ukrainian Party System before and after the 2013-2014 Euromaidan'. Europe-Asia Studies, 68(4): 609-630.

Franklin, Mark, Thomas Mackie, and Henry Valen (1992). Electoral Change: Responses to Evolving Social and Attitudinal Structures in Western Nations. Cambridge 1992: Cambridge University Press.

Gherghina, Sergiu (2014). Party Organisation and Electoral Volatility in Central and Eastern Europe: Enhancing Voter Loyalty. Routledge, London.

Gherghina, Sergiu (2016). 'Rewarding the "traitors": Legislative Defection and Re-Election in Romania'. Party Politics, 22(4): 490-500.

Harasymiw, Bohdan (2005). 'Elections in Post-Communist Ukraine, 1994-2004: An Overview'. Canadian Slavonic Papers, 47(3-4): 191-239.

Herron, Erik (2014). 'The parliamentary elections in Ukraine, October 2012'. Electoral Studies, 33(1): 353-356.

Hesli, Vicki L, William M. Resinger and Arthur H. Miller (1998), 'Political Party Development in Divided Societies: The Case of Ukraine'. Electoral Studies, 17(2): 235-256. 
Hobolt, Sara B and James Tilley (2016). 'Fleeing the Muddy: the Rise of Challenger Parties in the Aftermath of the Euro Crisis'. West European Politics, 39(5): 971-91.

Hutcheson, Derek S. (2011), 'The Seismology Of Psephology: 'Earthquake Elections' From The Folketing To The Dáil.' Representation 47 (4): 471-488.

Johnston, Richard (2013). 'Alignment, Realignment, and Dealignment in Canada: The View From Above'. Canadian Journal of Political Science 46 (2): 245-271.

Key, V.O. (1955). "A Theory of Critical Elections." The Journal of Politics, 17: 3-18.

Khmelko, Valeri and Andrew Wilson (1998) 'Regionalism and Ethnic and Linguistic Cleavages in Ukraine'. In Taras Kuzio (ed.), Contemporary Ukraine: Dynamics of PostSoviet Transition. Armunk NY: M.E. Sharpe.

Klecka, William R. (1980). Discriminant analysis. Quantitative Applications in the Social Sciences Series, No. 19. Sage Publications, Thousand Oaks, CA.

Kriesi, Hanpeter, Edgar Grande, Romain Lachat, Martin Dolezal, Simon Bornscheir, Timeos Frey (2006). 'Globaliziation and the Transformation of the National Political Space: Six European Countries Compared'. European Journal of Political Research, 45(6): 921-956.

Kubicek, Paul (2000). 'Regional Polarisation in Ukraine: Public Opinion, Voting and Legislative Behaviour'. Europe-Asia Studies, 52(2): 273-294.

Kuzio, Taras (2014). 'Impediments to the Emergence of Political Parties in Ukraine'. Politics, 34(4): 309-323.

Laakso, Markku, and Rein Taagepera (1979). 'Effective Number of Parties: A Measure with Application to West Europe'. Comparative Political Studies, 12(1): 3-27.

Lynch, P., R. Whitaker, et al. (2012). 'The UK Independence Party: Understanding a Niche Party's Strategy, Candidates and Supporters.' Parliamentary Affairs 65(4): 733-757.

McLachlan, Geoffry. J. (2004). Discriminant Analysis and Statistical Pattern Recognition. Wiley Interscience, New Jersey.

Marples, David (2015) 'Ethnic and Social Composition of Ukraine's Regions and Voting Patterns'. In Richard Sakwa and Agnieszka Pikulicka-Wilczewska (eds.) Ukraine and Russia: People, Politics, Propaganda and Perspectives (E-International Relations). Available at http://www.e-ir.info/2015/03/10/ethnic-and-social-composition-of-ukraines-regions-andvoting-patterns/ (Accessed 22 January 2018). 
Mayhew, David (2002). Electoral Alignments: A Critique of an American Genre. Yale University Press: New Haven.

Meguid, B. M. (2005). 'Competition Between Unequals: The Role of Mainstream Party Competition in Niche Party Success'. American Political Science Review, 99(3): 327-346.

Mykhnenko, Vlad (2009). 'Class Voting and the Orange Revolution: A Cultural Political Economy Perspective on Ukraine's Political Geography'. Journal of Communist Studies and Transition Politics, 25(2-3): 278-296.

Oesch, Daniel (2008). 'The Changing Shape of Class Voting: An Individual-level Analysis of Party Support in Britain, Germany and Switzerland'. European Societies, 10(3): 329-355.

O’Loughlin, John (2001). 'The Regional Factor in Contemporary Ukrainian Politics: Scale, Place, Space, or Bogus Effect?', Post-Soviet Geography and Economics, 42 (1): 1-33.

Onuch, Olga (2015). 'EuroMaidan Protests in Ukraine: Social Media Versus Social Networks.' Problems of Post-Communism, 62 (4): 217-235.

Rohrschneider, Robert and Stephen Whitefield (2016). 'Responding to Growing EUskepticism? The Stances of Political Parties Towards European Integration in Western and Eastern Europe Following the Financial Crisis', European Union Politics, 17(1): 138-161. Roper, Steven D and Florin Fesnic (2003). 'Historical Legacies and their Impact on PostCommunist Voting Behaviour'. Europe-Asia Studies, 55(1): 119-131.

Rae, Douglas (1967). Political Consequences of Electoral Laws. New Haven: Yale University Press.

Rovny, Jan (2014), 'Communism, Federalism, and Ethnic Minorities: Explaining Party Competition Patterns in Eastern Europe”. World Politics, 66(4): 669-708.

Rovny, Jan and Jonathan Polk (2018), 'New Wine in Old Bottles: Explaining the Dimensional Structure of European Party Competition', Party Politics, on-line first. Rybiy, Olena. 2013. 'Party System Institutionalization in Ukraine.' Demokratizatsiya 21(3): 401-423.

Schattschneider, E.E. (1958). Equilibrium and Change in American Politics. University of Maryland. 
Schofield, Norman, Gary Miller and Andrew Martin (2003). 'Critical Elections and Political Realignments in the USA: 1860-2000'. Political Studies, 51: 217-240.

Shevel, Oxana (2015). 'The Parliamentary Elections in Ukraine, October 2014'. Electoral Studies, 39(3): 153-177.

Sniderman, Paul, Richard Brody and Philip Tetlock (1991). Reasoning and choice. Stanford, CA: Stanford University Press.

Sundquist, James L. (1973). Dynamics of the Party System: Alignment and Realignment of Political Parties in the United States. University of Chicago Press: Chicago.

Tavits, Margit (2008). 'On the Linkage between Electoral Volatility and Party System Instability in Central and Eastern Europe'. European Journal of Political Research 47(5): 537-555.

Whitefield, Stephen (2002). 'Political Cleavages and Post-Communist Politics', Annual Review of Political Science, 5, 181-200.

Whitefield , Stephen, 2006. Between East and West: Attitudes towards Political and Economic Integration in Russia and Ukraine, 1993-2001. in Rohrschneider, Robert, Whitefield, Stephen (Eds.) Public Opinion, Party Competition and the European Union in Eastern Europe, Palgrave: London.

Whitefield, Stephen and Geoffrey Evans (2000), 'Explaining the Formation of Electoral Cleavages in Post-Communist Democracies', in H-D. Klingemann, E. Mochmann and K. Newton eds., Elections in Central and Eastern Europe: The First Wave, Sigma, Berlin, pp.36-70.

Whitefield, Stephen and Robert Rohrschneider (2009). 'Representational Consistency: Stability and Change in Political Cleavages in Central and Eastern Europe'. Politics and Policy, 37(5), 667-690.

Wilson, Andrew (1997) Ukrainian Nationalism in the 1990s: A Minority Faith. Cambridge: Cambridge University Press.

Wilson, Andrew (2015) Ukraine Crisis: What It Means for the West. Yale: Yale University Press. 
Wilson, Andrew and Sarah Birch (1999), 'Voting Stability, Political Gridlock: Ukraine's 1998 Parliamentary Elections', Europe-Asia Studies, 51(6): 1039-1068.

Wilson, Andrew and Sarah Birch (2007), 'Political Parties in Ukraine.' In Paul Webb and

Stephen White (eds.) Party Politics in New Democracies. Oxford University Press: Oxford.

\section{Figure 1: Ukrainian Party Fragmentation in Global Perspective}

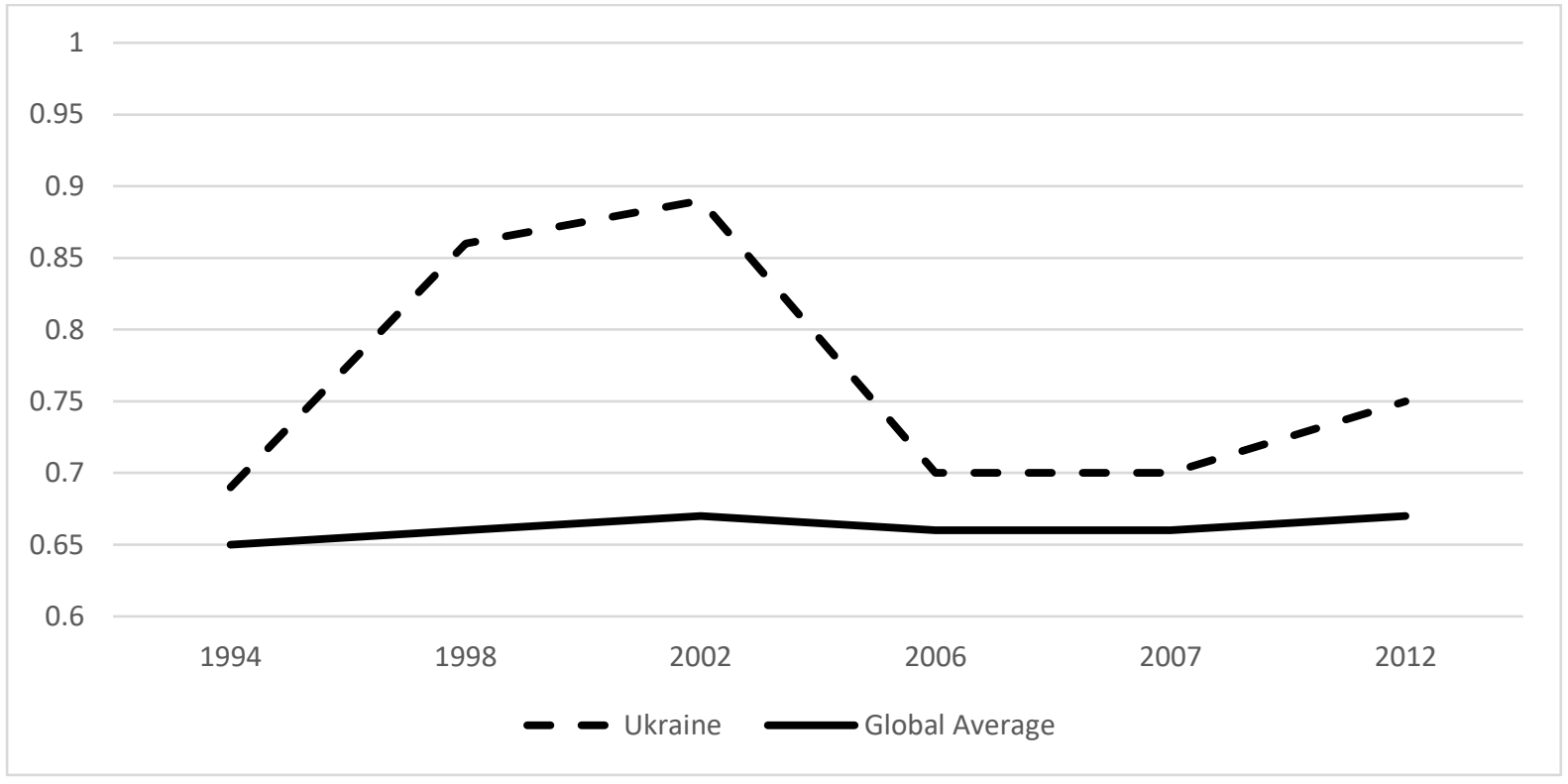

Note: Regimes are included here only if they are classified by Polity IV as "open anocracies" ( 1 to 5 on the Polity scale) or "democracies" (6 to 10). These data are calculated using Rae's (1967) measure of fractionalization, representing the probability that two randomly selected members of the assembly will belong to different political parties. Rae's measure of fractionalization can be converted to the effective number of parties (Laakso and Taagepera 1979) using the formula $\mathrm{N}=1 /(1-\mathrm{F})$. 
Table 1: Distribution of Party Voters by Survey, 1995 - 2014

\begin{tabular}{|c|c|c|c|c|}
\hline Survey wave & 1995 & 1998 & 2007 & 2014 \\
\hline Party voters & $\begin{array}{l}\text { Communist } \\
(125) \\
\text { Democratic } \\
\text { Party (79) } \\
\text { Rukh (103) } \\
\text { Socialist (126) }\end{array}$ & $\begin{array}{l}\text { Agrarian (50) } \\
\text { Communist } \\
\text { (577) } \\
\text { Green (145) } \\
\text { Hromada (80) } \\
\text { National } \\
\text { Democratic (78) } \\
\text { National Front } \\
\text { (54) } \\
\text { Progressive } \\
\text { Socialist (79) } \\
\text { Rukh (180) } \\
\text { Socialist (77) } \\
\text { Social } \\
\text { Democratic (76) } \\
\text { Together (53) }\end{array}$ & $\begin{array}{l}\text { Communist (62) } \\
\text { Lutsenko Bloc (52) } \\
\text { Our Ukraine (170) } \\
\text { Party of Regions } \\
(515) \\
\text { Tymoshenko Bloc } \\
(260)\end{array}$ & $\begin{array}{l}\text { Fatherland } \\
(61) \\
\text { Freedom (71) } \\
\text { Opposition } \\
\text { Bloc (104) } \\
\text { Popular Front } \\
\text { (254) } \\
\text { Poroshenko } \\
\text { Bloc (440) } \\
\text { Radical Party } \\
\text { (107) } \\
\text { Self Reliance } \\
\text { (160) }\end{array}$ \\
\hline $\begin{array}{l}\text { Number of } \\
\text { respondents (\% } \\
\text { share of total } \\
\text { survey } \\
\text { respondents) }\end{array}$ & $433(17.3 \%)$ & $1449(57.9 \%)$ & $1059(70.6 \%)$ & $1197(50.3)$ \\
\hline
\end{tabular}


Table 2. Discriminant Analysis of Attitudinal Variables

\begin{tabular}{|c|c|c|}
\hline Year & $\begin{array}{c}\text { Eigenvalue Function } \\
\text { (variables) }\end{array}$ & \% of variance \\
\hline $\mathbf{1 9 9 5}$ & $\begin{array}{c}\text { 1. Dissolution of USSR, } \\
\text { Support for Democracy }\end{array}$ & 93.6 \\
\hline $\mathbf{1 9 9 8}$ & 1. Dissolution of USSR & 89.6 \\
\hline $\mathbf{2 0 0 7}$ & $\begin{array}{c}\text { 1. Language in Schools, } \\
\text { Dissolution of USSR, } \\
\text { Integration with EU }\end{array}$ & 97.4 \\
\hline $\mathbf{2 0 1 4}$ & $\begin{array}{c}\text { 1. Integration with EU } \\
\text { (including abstainers in South/East) }\end{array}$ & $\begin{array}{c}\text { 1. Integration with EU } \\
\text { Dissolution of USSR }\end{array}$ \\
\hline $\mathbf{2 0 1 4}$ & 97.2 \\
\hline
\end{tabular}


Table 3: Likelihood Ratio Tests of Demographic and Socio-Economic Predictors with Chi-Square Statistics and P-values

\begin{tabular}{|l|l|l|l|l|l|}
\hline & $\begin{array}{l}\text { Young voter (18- } \\
\text { 34) }\end{array}$ & $\begin{array}{l}\text { Deteriorating } \\
\text { standard of } \\
\text { living (past 5 } \\
\text { years) }\end{array}$ & $\begin{array}{l}\text { Regular church } \\
\text { attendance } \\
\text { (weekly/monthly) }\end{array}$ & $\begin{array}{l}\text { Resident in the } \\
\text { East/South }\end{array}$ & $\begin{array}{l}\text { Russian } \\
\text { language } \\
\text { speaker (at } \\
\text { home) }\end{array}$ \\
\hline 1995 & 5.98 & 4.296 & 2.451 & $23.96 * * *$ & $13.966 * *$ \\
\hline 1998 & $118.043 * * *$ & $33.174 * * *$ & $81.569 * * *$ & $188.721 * * *$ & $72.201 * * *$ \\
\hline 2007 & $49.087 * * *$ & 1.354 & $26.15 * * *$ & $171.158^{* * *}$ & $44.312 * * *$ \\
\hline 2014 & $19.454 * *$ & $17.039 * *$ & 7.085 & $64.279 * * *$ & $29.78 * * *$ \\
\hline
\end{tabular}

$* * \mathrm{p}<0.01 ; * * * \mathrm{p}<0.001$ 
Figure 2 Scatter Plots of Party Voter Positioning on the Two Primary Issue Dimensions at the 1994, 1998, 2007 and 2014 Ukrainian Rada Elections

a. 1994

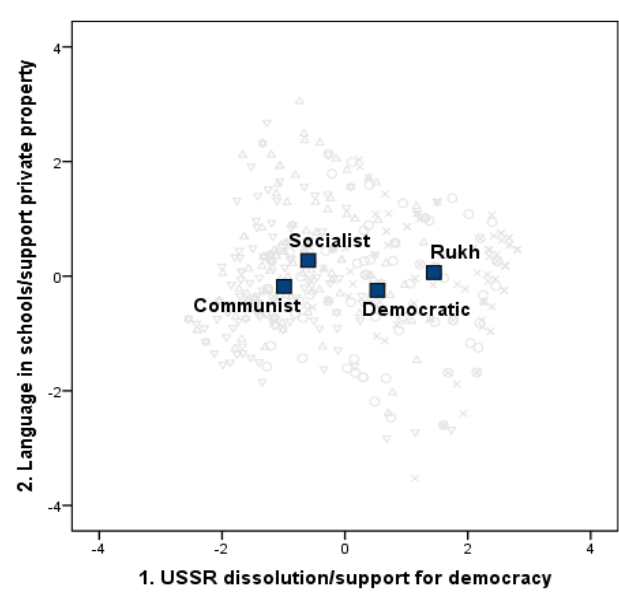

d. 2014

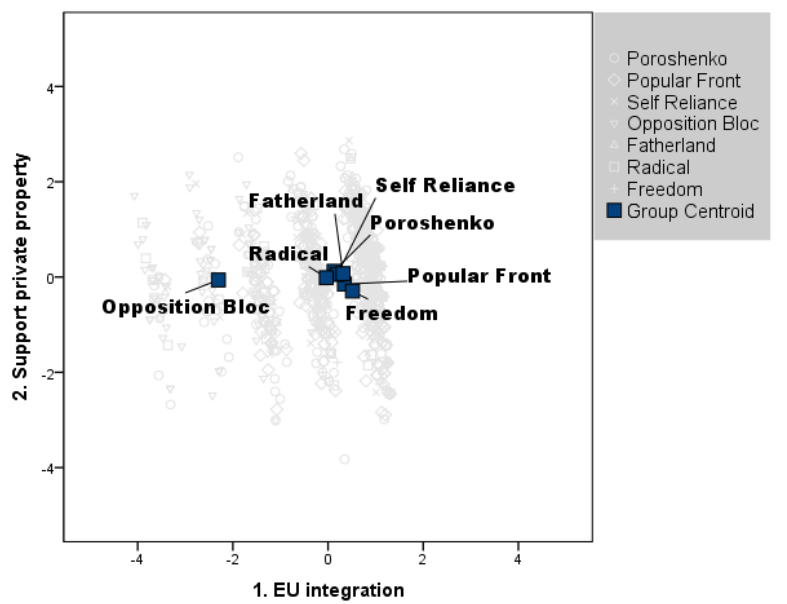

b. 1998

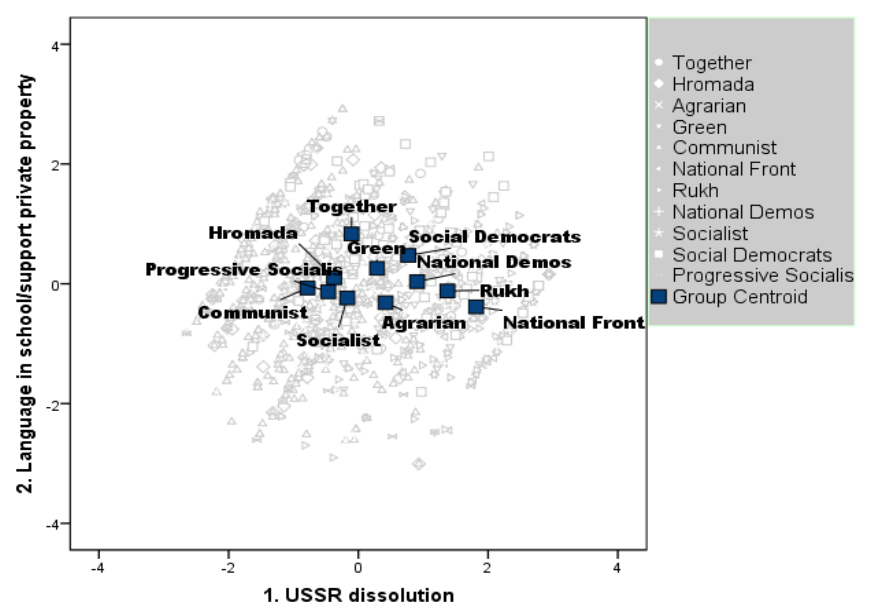

e. 2014 (incl. South/East abstainers)

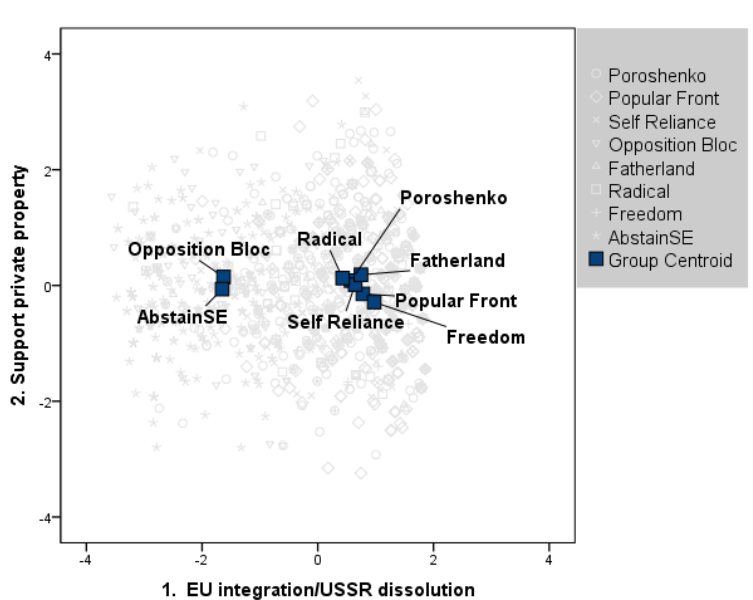

c. 2007

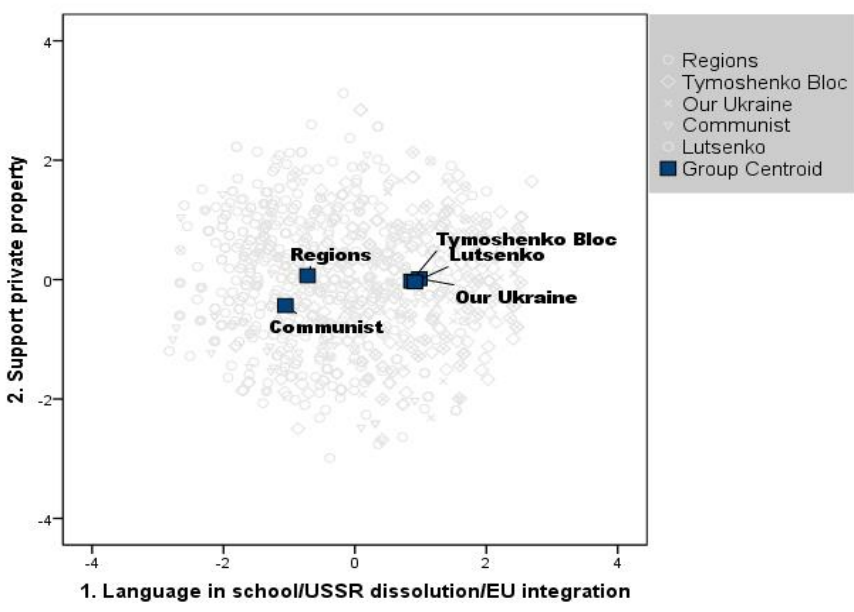


Figure 3: Probability that Party Voters Reside in the East or South

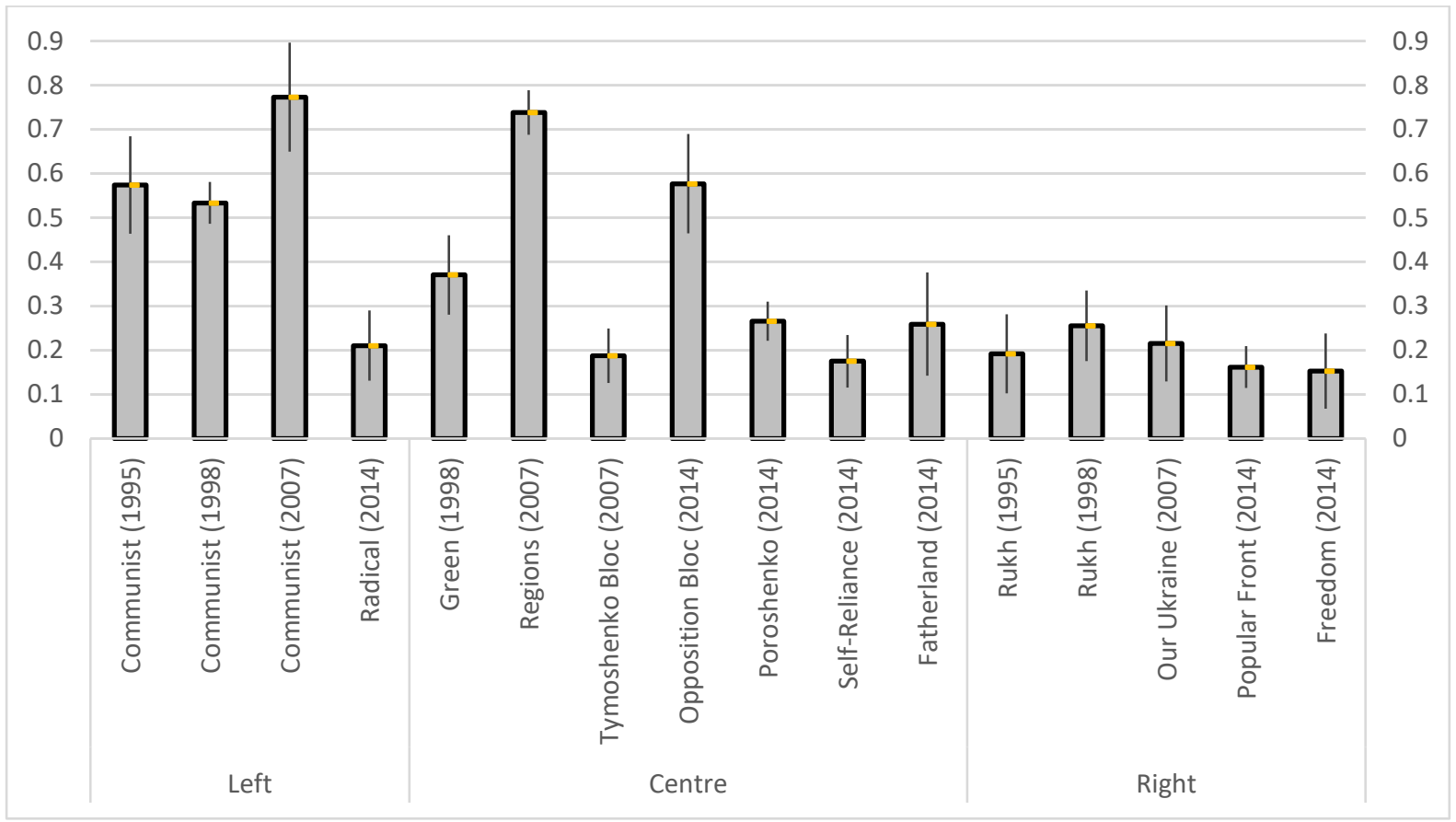


Figure 4: Probability that Party Voters are Russian Language Speakers

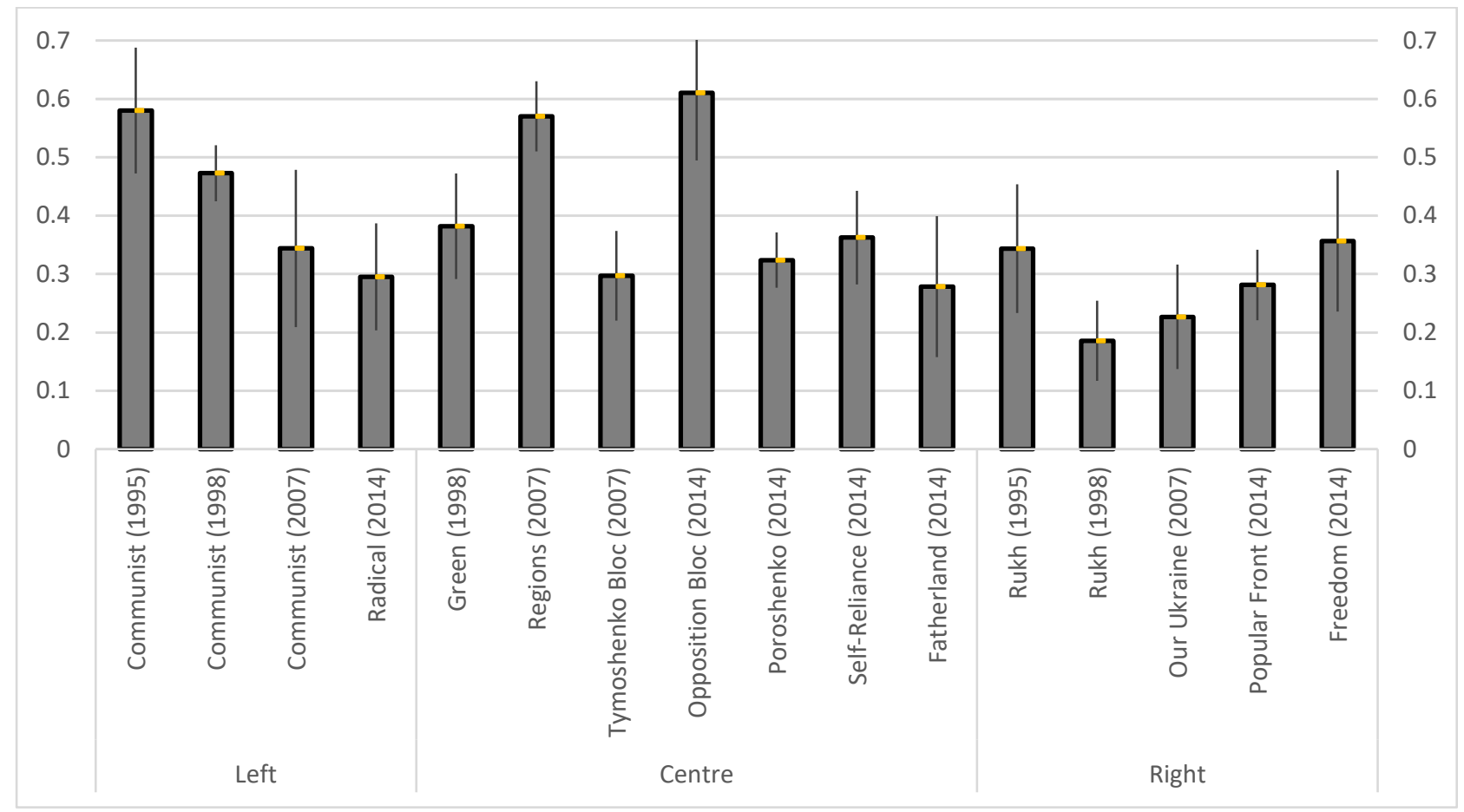




\section{Appendix A: The Surveys}

\begin{tabular}{|c|c|c|c|}
\hline & SAMPLING FRAME & SAMPLING & RESPONSE RATE \\
\hline $\begin{array}{l}\text { SUMMER } \\
1995\end{array}$ & $\begin{array}{l}\text { Adult pop (16+) } \\
\text { Housing Offices' } \\
\text { residence list of } \\
\text { individuals }\end{array}$ & $\begin{array}{l}\text { 1. } 90 \text { urban + } 90 \text { rural } \\
\text { settlements, random } \\
\text { selection } \\
\text { 2. } 5 \text { types of urban } \\
\text { settlements; selection } \\
\text { proportional to size of } \\
\text { pop. in each type; } \\
\text { random selection of } \\
\text { rural settlements. } \\
\text { 3. Multistage } \\
\text { probability sampling } \\
\text { and random route. }\end{array}$ & $\begin{array}{l} \\
\text { Names issued: } \\
3788 \\
\text { Non-contact: } \\
\text { Refused: } \\
\text { Achieved: } \\
\text { 2500 } \\
\text { Response rate } \quad 0.668\end{array}$ \\
\hline $\begin{array}{l}\text { SUMMER } \\
1998\end{array}$ & $\begin{array}{l}\text { Adult pop (18+) } \\
\text { Electoral register }\end{array}$ & $\begin{array}{l}\text { 1. } 1.4 \text { economic- } \\
\text { geographical zones; } 15 \\
\text { clusters; } \\
\text { 2. } 49 \text { raions+2 (Moscow } \\
\text { and St. Petersburg) } \\
\text { sampling points; } \\
\text { 3. } 51 \text { communities; } \\
\text { 4.Multistage probability } \\
\text { sampling and random } \\
\text { route with Kish Grid } \\
\text { selection }\end{array}$ & $\begin{array}{l}\text { Names issued: } 3137 \\
\text { Non-contact: } 982 \\
\text { Refused: } \\
\text { Achieved: } \\
2008 \\
\text { Response rate: } 0.64\end{array}$ \\
\hline
\end{tabular}




\begin{tabular}{|c|c|c|c|}
\hline $\begin{array}{l}\text { SUMMER } \\
2007\end{array}$ & Census & $\begin{array}{l}\text { Stage 1: Territorial- } \\
\text { Administrative Unit (7 } \\
\text { regions) } \\
\text { Stage 2: Settlement } \\
\text { (allocated to } 6 \text { strata in } \\
\text { proportion to the } \\
\text { population of each } \\
\text { stratum); } \\
\text { Stage 3: Sampling } \\
\text { Location (PSU) } \\
\text { Stage 4: Random Route } \\
\text { for selecting households } \\
\text { and The most recent } \\
\text { birthday method for } \\
\text { selecting respondents } \\
\end{array}$ & $\begin{array}{l}\text { Total Contacts: } 4901 \\
\text { Respondent non- } \\
\text { contact: } 2515 \\
\text { Respondent Contact: } \\
2386 \\
\text { Achieved: } 1500 \\
\text { Response Rate: } 0.63\end{array}$ \\
\hline $\begin{array}{l}\text { WINTER } \\
2014\end{array}$ & $\begin{array}{l}\text { Adult population (18+) } \\
\text { Control Quota on age, } \\
\text { sex and education }\end{array}$ & $\begin{array}{l}\text { Stratification } \\
\text { Method } \\
\text { Stage 1: Selection of } \\
\text { regions (6 regions as used } \\
\text { in the official statistics) } \\
\text { Stage 2: Selection of } \\
\text { settlement (allocated to } 6 \\
\text { strata in proportion to the } \\
\text { population of each } \\
\text { stratum) } \\
\text { Stage 3: Selection of } \\
\text { random routes* } \\
\text { Stage 4: Selection of } \\
\text { households (random route } \\
\text { method with a pre- } \\
\text { determined starting point) } \\
\text { Stage 5: Selection of } \\
\text { respondents within } \\
\text { households (the most } \\
\text { recent birthday method; } \\
\text { only one respondent per } \\
\text { household was } \\
\text { interviewed) }\end{array}$ & $\begin{array}{l}\text { Successful contacts } \\
\text { Completed interviews: } \\
2308 \\
\text { Non-contacts } \\
\text { i) Eligible respondent } \\
\text { refused: } 742 \\
\text { ii) Household } \\
\text { unreachable } 1538 \\
\text { iii) Eligible respondents } \\
\text { unreachable } 337 \\
\text { iv) Empty dwelling } 75 \\
\text { Response Rate: } 0.47^{11}\end{array}$ \\
\hline
\end{tabular}

${ }^{11}$ The significant displacement of people in Donetsk and Luhansk meant we were unable to obtain a full probability sample in these occupied territories in the 2014 survey. ${ }^{11}$ Given the geographically skewed nature of the distribution of the local population in both regions, quota 


\section{Appendix B: Descriptive Statistics for All Variables}

\begin{tabular}{|c|c|c|c|c|c|}
\hline Variable & Mean & Median & Min & $\operatorname{Max}$ & $S D$ \\
\hline \multicolumn{6}{|l|}{ Attitudinal variables } \\
\hline $\begin{array}{l}\text { Dissolution of USSR } \\
2014 \\
2007 \\
1998 \\
1995\end{array}$ & $\begin{array}{l}3.42 \\
2.68 \\
2.43 \\
2.44\end{array}$ & $\begin{array}{l}3.00 \\
2.00 \\
2.00 \\
2.00\end{array}$ & $\begin{array}{l}1 \\
1 \\
1 \\
1\end{array}$ & $\begin{array}{l}5 \\
5 \\
5 \\
5\end{array}$ & $\begin{array}{l}1.248 \\
1.450 \\
1.460 \\
1.466\end{array}$ \\
\hline $\begin{array}{l}\text { EU integration/isolation } \\
2014 \\
2007 \\
1998 \\
1995\end{array}$ & $\begin{array}{l}4.23 \\
3.52 \\
3.43 \\
3.72 \\
\end{array}$ & $\begin{array}{l}5.00 \\
4.00 \\
3.00 \\
4.00 \\
\end{array}$ & $\begin{array}{l}1 \\
1 \\
1 \\
1 \\
\end{array}$ & $\begin{array}{l}5 \\
5 \\
5 \\
5 \\
\end{array}$ & $\begin{array}{l}1.068 \\
1.254 \\
1.220 \\
1.179 \\
\end{array}$ \\
\hline $\begin{array}{l}\text { Democracy - best system } \\
2014 \\
2007 \\
1998 \\
1995\end{array}$ & $\begin{array}{l}3.92 \\
3.12 \\
3.08 \\
3.27\end{array}$ & $\begin{array}{l}4.00 \\
3.00 \\
3.00 \\
4.00\end{array}$ & $\begin{array}{l}1 \\
1 \\
1 \\
1\end{array}$ & $\begin{array}{l}5 \\
5 \\
5 \\
5\end{array}$ & $\begin{array}{l}.962 \\
1.174 \\
1.166 \\
1.249\end{array}$ \\
\hline $\begin{array}{l}\text { Market economy - best system } \\
2014 \\
2007 \\
1998 \\
1995\end{array}$ & $\begin{array}{l}3.72 \\
3.15 \\
3.26 \\
3.35 \\
\end{array}$ & $\begin{array}{l}4.00 \\
3.00 \\
4.00 \\
4.00 \\
\end{array}$ & $\begin{array}{l}1 \\
1 \\
1 \\
1 \\
\end{array}$ & $\begin{array}{l}5 \\
5 \\
5 \\
5 \\
\end{array}$ & $\begin{array}{l}.912 \\
1.137 \\
1.206 \\
1.283 \\
\end{array}$ \\
\hline $\begin{array}{l}\text { Ukrainian language in all schools } \\
2014 \\
2007 \\
1998 \\
1995\end{array}$ & $\begin{array}{l}3.55 \\
3.13 \\
3.07 \\
2.97\end{array}$ & $\begin{array}{l}4.00 \\
3.00 \\
3.00 \\
3.00\end{array}$ & $\begin{array}{l}1 \\
1 \\
1 \\
1\end{array}$ & $\begin{array}{l}5 \\
5 \\
5 \\
5\end{array}$ & $\begin{array}{l}1.037 \\
1.354 \\
1.415 \\
1.367\end{array}$ \\
\hline \multicolumn{6}{|l|}{$\begin{array}{l}\text { Socio-economic and demographic } \\
\text { variables }\end{array}$} \\
\hline $\begin{array}{l}\text { Southern and Eastern Region } \\
2014 \\
2007 \\
1998 \\
1995\end{array}$ & $\begin{array}{l}.27 \\
.49 \\
.43 \\
.41 \\
\end{array}$ & $\begin{array}{l}0 \\
0 \\
0 \\
0 \\
\end{array}$ & $\begin{array}{l}0 \\
0 \\
0 \\
0 \\
\end{array}$ & $\begin{array}{l}1 \\
1 \\
1 \\
1 \\
\end{array}$ & $\begin{array}{l}.447 \\
.500 \\
.495 \\
.492 \\
\end{array}$ \\
\hline $\begin{array}{l}\text { Russian Language Speaker } \\
2014 \\
2007 \\
1998 \\
1995\end{array}$ & $\begin{array}{l}.36 \\
.45 \\
.40 \\
.44 \\
\end{array}$ & $\begin{array}{l}0 \\
0 \\
0 \\
0\end{array}$ & $\begin{array}{l}0 \\
0 \\
0 \\
0\end{array}$ & $\begin{array}{l}1 \\
1 \\
1 \\
1 \\
\end{array}$ & $\begin{array}{l}.480 \\
.498 \\
.489 \\
.497 \\
\end{array}$ \\
\hline
\end{tabular}

sampling was used for respondent selection within each household. Households within randomly chosen settlements were selected using a random routes sampling technique. 


\begin{tabular}{|l|l|l|l|l|l|}
\hline Age & .47 & 0 & 0 & 1 & .499 \\
2014 & .41 & 0 & 0 & 1 & .492 \\
2007 & .36 & 0 & 0 & 1 & .482 \\
1998 & .33 & 0 & 0 & 1 & .473 \\
1995 & .32 & 0 & 0 & 1 & .467 \\
\hline Regular Church Attendee & .28 & 0 & 0 & 1 & .451 \\
2014 & .16 & 0 & 0 & 1 & .364 \\
2007 & .18 & 0 & 0 & 1 & .381 \\
1998 & .68 & 1 & 0 & 1 & .466 \\
1995 & .32 & 0 & 0 & 1 & .469 \\
\hline Economic Affluence (last 5 years) & .87 & 1 & 0 & 1 & .326 \\
2014 & .90 & 1 & 0 & 1 & .289 \\
2007 & & & & \\
1998 & & & & & \\
1995 & & & & & \\
\hline
\end{tabular}


Appendix C: Table 3: Likelihood Ratio Tests of Demographic and Socio-Economic Predictors with Chi-Square Statistics and P-values

\begin{tabular}{|l|l|l|l|l|l|}
\hline & $\begin{array}{l}\text { Dissolution } \\
\text { of USSR }\end{array}$ & $\begin{array}{l}\text { Democracy - } \\
\text { best system }\end{array}$ & $\begin{array}{l}\text { EU } \\
\text { integration/isolation }\end{array}$ & $\begin{array}{l}\text { Market } \\
\text { economy - } \\
\text { best system }\end{array}$ & $\begin{array}{l}\text { Ukraine language } \\
\text { in all schools }\end{array}$ \\
\hline 1995 & $90.595^{* * *}$ & 12.268 & 16.501 & $24.075^{* *}$ & $35.84 * * *$ \\
\hline 1998 & $233.86^{* * *}$ & $64.174^{* *}$ & $89.935^{* * *}$ & $98.93^{* * *}$ & $147.234 * * *$ \\
\hline 2007 & $142.632^{* * *}$ & 22.499 & $73.384 * * *$ & 16.098 & $158.553^{* * *}$ \\
\hline 2014 & $37.558^{*}$ & $35.614^{*}$ & $154.342^{* * *}$ & $46.904 * *$ & $59.101^{* * *}$ \\
\hline $\begin{array}{l}2014 \text { (with } \\
\text { abstainers in } \\
\text { South/East) }\end{array}$ & $60.17^{* * *}$ & $46.091^{*}$ & $322.8 * * *$ & $48.425^{* *}$ & $122.912^{* * *}$ \\
\hline
\end{tabular}

${ }^{*} \mathrm{p}<0.05 * * \mathrm{p}<0.01 ; * * \mathrm{p}<0.00$ 
